\title{
Hydridothiazole Rhodium Complexes as a Result of C-H Bond Activation in Iminothiazoles Chelating Ligands
}

\author{
Jehan Al-hamidi ${ }^{1}$, Abdulhamid Alsaygh ${ }^{2}$ and Ibrahim Al-Najjar ${ }^{2, *}$ \\ ${ }^{1}$ Chemistry Department, College of Science, Princess Nora Bent Abdullrahman University, Riyadh, Saudi Arabia; \\ ${ }^{2}$ Petrochemicals Research Institute, King Abdulaziz City for Science and Technology, P. O. Box 6086, Riyadh-11442, \\ Saudi Arabia
}

\begin{abstract}
A series of 20 Schiff base ligands derived from 2-aminothiazole and its derivatives and aryl aldehydes with either $\left[\mathrm{RhCl}\left(\mathrm{PPh}_{3}\right)_{3}\right]$ or $[\mathrm{Rh}(\mu-\mathrm{Cl})(\mathrm{COD})]_{2}$ in the presence of 4 equivalents of $\mathrm{PPh}_{3}$ lead to an $\mathrm{Rh}(\mathrm{III})$ cyclometallated complex and the imine ligand $(\mathrm{C}-\mathrm{H})$ bond has been added to the metal $(\mathrm{C}-\mathrm{M}-\mathrm{H})$. The complexes were investigated by using I.R., ${ }^{1} \mathrm{H},{ }^{13} \mathrm{C}$ and ${ }^{31} \mathrm{P}$ NMR Spectroscopic techniques. The signal of the $(\mathrm{C}-\mathrm{H})$ ligand was observed as trans to the nitrogen atom in the complex which is a donor ligand.
\end{abstract}

Graphical Abstract: Total synthesis of hydridothiazole rhodium complexes possessing rhodium hydride signal at $\delta$ $\left(-14.60\right.$ to-15.04) ppm, trans to $\mathrm{N}$-donor ligand and iminoyl carbon $\left({ }^{7} \mathrm{C}=\mathrm{N}\right)$ signal in $\mathrm{Rh}(\mathrm{III})$ observed at $\delta(220.1-237.6)$ ppm, lower field and suggestive of carbine like properties.

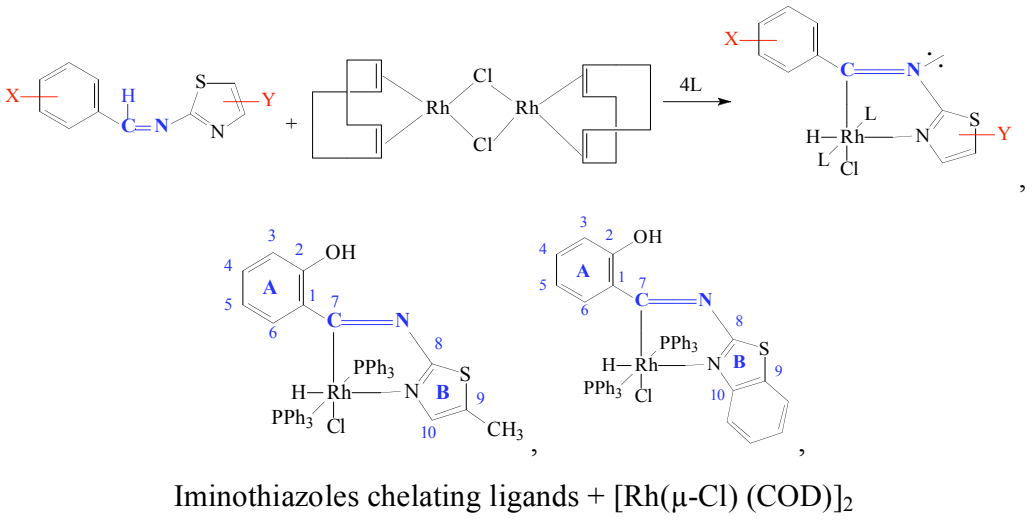

Keywords: Hydrido complexes, ligand substitution, IR,1H,13C,31P NMR, oxidative-addition, phosphine complexes, rhodium, Schiff-bases.

\section{INTRODUCTION}

The oxidative addition of $\mathrm{C}-\mathrm{H}$ bond activated by transition metal has been reported in many recent studies in organometallic chemistry [1-4]. Benzylic imines $(\mathrm{Ph}-\mathrm{CH}=$ $\mathrm{NR}$ ) are the most studied ligands in the cyclometallation of transition metals $[5,6]$. It has been reported that intramolecular $\mathrm{C}-\mathrm{H}$ activation examples of rhodium with $\mathrm{N}$ donar ligands and $\mathrm{C}-\mathrm{X}$ (X: halogen) activation with imines [2-4, 7-9]. The first report of ortho-metallation of imines at rhodium via $\mathrm{C}-\mathrm{H}$ activation has appeared only recently [2-4, 10]. Interestingly, cyclometallation reaction of imine [11] C$\mathrm{H}$ bonds leads us to study some of the important chemistry related to the imines, derivatives from 2-aminothiazole and its derivatives and aryl aldehydes. In most recent application for ruthenium, rhodium and iridium complexes have been

*Address correspondence to this author at the Petrochemicals Research Institute, King Abdulaziz City for Science and Technology, P. O. Box 6086, Riyadh - 11442, Saudi Arabia; Tel: +966 504269199;

E-mail: alnajjar@kacst.edu.sa used as therapeutic agents and a number of kinetically inert ruthenium(II), iridium(III) and rhodium(III) complexes have been reported as inhibitors of protein kinases [12-16]. Chung-Hang Leung and Dik-Lung Ma group have also actively pursued the development of kinetically inert metal complexes as inhibitors of various bimolecular targets, including DNA, enzymes and protein-protein interactions [13]. Here, we report the synthesis and characterization of many new rhodium (III) complexes of (X - (substituted benzylidene amino) thiazoles.

\section{MATERIAL AND METHODOLOGY}

CHEMICALS: All techniques and operations were performed under nitrogen using Schlenk techniques. Substituted aryl aldehydes, $\mathrm{RhCl}_{3} \cdot \mathrm{xH}_{2} \mathrm{O}, \mathrm{Ph}_{3} \mathrm{P}$, cyclo-1, 5-octadien, and 2- aminothiazoles derivatives were purchased from Winlab, Aldrich and Strem chemicals, and were used as received.

\subsection{Schiff Bases Syntheses}

The Schiff bases were synthesized by adding equivalent amounts of aryl aldehydes and 2-aminothiazole derivatives 


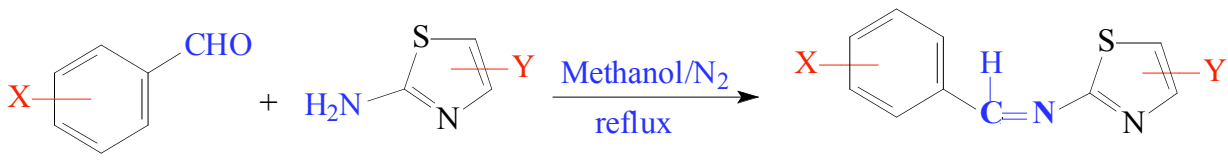

Eq. (1). Describes schematic diagram for the preparation of Schiff bases (No. 1-15): $\mathrm{X}, 1=-\mathrm{H}, 2=2-\mathrm{OH}, 3=4-\mathrm{NO}_{2}, 4=4-\mathrm{Br}, 5=3-\mathrm{OH}, 6$ $=2-\mathrm{NO}_{2}, 7=3-\mathrm{Me}$ (compounds from: 1-7, $\left.\mathrm{Y}=\mathrm{H}\right) \mathrm{8}, \mathrm{Y}=4-\mathrm{CH}_{3}(\mathrm{X}=\mathrm{H}), 9, \mathrm{Y}=4-\mathrm{Me}(\mathrm{X}=2-\mathrm{OH}), 10, \mathrm{Y}=4-\mathrm{Me}\left(\mathrm{X}=4-\mathrm{NO}_{2}\right), 11, \mathrm{Y}=4-$ $\mathrm{Me},(\mathrm{X}=4-\mathrm{Br}), 12, \mathrm{Y}=5-\mathrm{Me},(\mathrm{X}=\mathrm{H}), 13, \mathrm{Y}=5-\mathrm{Me},(\mathrm{X}=2-\mathrm{OH}), 14, \mathrm{Y}=5-\mathrm{Me},\left(\mathrm{X}=4-\mathrm{NO}_{2}\right), 15, \mathrm{Y}=5-\mathrm{Me},(\mathrm{X}=4-\mathrm{Br})$.

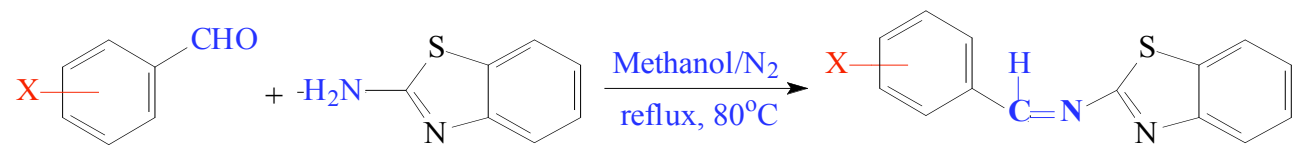

Eq. (2). Compound (No.16), $\mathrm{X}=2-\mathrm{OH}$.

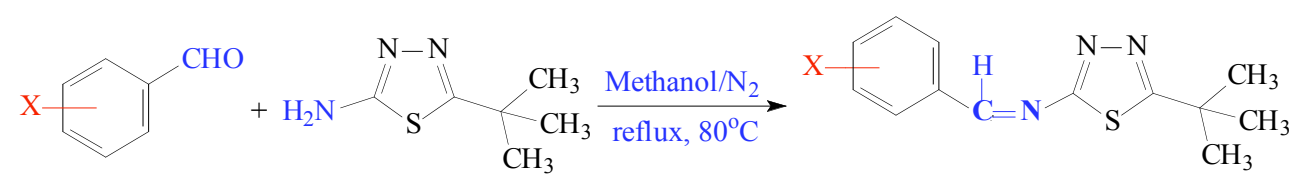

Eq. (3). Compound (No.17): $\mathrm{X}=\mathrm{H},(18), \mathrm{X}=2-\mathrm{OH},(19), \mathrm{X}=4-\mathrm{NO}_{2},(20), \mathrm{X}=4-\mathrm{Br}$.

in $80 \mathrm{ml}$ methanol. The resulting mixture was boiled under reflux and stirred for $9 \mathrm{~h}$ at $80^{\circ} \mathrm{C}$ in an oil bath, and then the solvent was concentrated by using rotary evaporation to give brown viscous liquid. Then n-hexane was added to precipitate the crude product, which was then recrystallized in dichloromethane and with n-hexane to give white precipitate, dried, yield $50-70 \%$ scheme (1), (the full characterization of the resulting Schiff base was submitted for publication in Arab Gulf Journal of Scientific Research (AGJSR), 2014.

\subsection{Syntheses of the Cyclometallated Schiff Base Com- plexes}

The rhodium (III) complexes were synthesized by reaction of the Schiff base with either $\left\{\mathrm{RhCl}\left(\mathrm{Ph}_{3} \mathrm{P}\right)_{3}\right\}$ or $[\mathrm{Rh}(\mu-$ $\mathrm{Cl})(\mathrm{COD})]_{2}$. $[17,18]$. Here, we report two examples:

a. A solution of $\left\{\mathrm{Rh} \mathrm{Cl}\left(\mathrm{PPh}_{3}\right)_{3}\right\} \quad(300 \mathrm{mg}, 0.325 \mathrm{mmol})$ mixed with an equivalent amount of thiazole imines in 20 $\mathrm{cm}$ of dry THF was refluxed for $1 \mathrm{~h}$ under nitrogen atmosphere, then allowed to cool. Addition of n-hexane precipitated the product, the resulting product gave yellow solid, which was separated and (recrystallized from $\mathrm{CH}_{2} \mathrm{Cl}_{2}$ /hexane).

b. A solution of $\{\mathrm{Rh}(\mu \mathrm{Cl})(\mathrm{COD})\} 2(200 \mathrm{mg}, 0.28 \mathrm{mmol})$, thiazole Schiff base $(0.56 \mathrm{mmol})$ and $\mathrm{PPh}_{3}(293 \mathrm{mg}, 1.12$ mmol) in ca. $20 \mathrm{~cm}^{3}$ of dry THF was refluxed for $1 \mathrm{~h}$, and by addition of n-hexane, the product was precipitated, which was separated by filtration and (recrystallized from $\mathrm{CH}_{2} \mathrm{Cl}_{2}$ /hexane).

\subsection{Spectroscopy}

I.R. spectra were measured using Nexus spectrophotometer FT IR. The N.M.R. spectra were recorded at R.T. on a JEOL $400 \mathrm{MHz}$. The ${ }^{1} \mathrm{H},{ }^{13} \mathrm{C}(1 \mathrm{H})$ and ${ }^{31} \mathrm{P}\left[{ }^{1} \mathrm{H}\right]-\mathrm{n}$. m. r. frequencies observated at 400, 100 and $161.08 \mathrm{MHz}$ respectively (at JEOL). Positive values for ${ }^{31} \mathrm{P}-\left[{ }^{1} \mathrm{H}\right]$ representing deshielding. The cyclometallated complexes) were dissolved in $\mathrm{CDCl}_{3}$.

\section{RESULTS AND DISCUSSION}

Introducing metal into $\mathrm{C}-\mathrm{H}$ bond have been observed in many compounds like quinoline and Schiff base substrates [19]. A significant amount of work has been done on the heterocyclic aromatic species, 8-substituted quinoline [20-24] and 2- (benzylidenamino) pyridines [25-29]. Coordination of the metal with nitrogen atom in aryl amines results in a favorable geometry for introducing of the metal into neighboring $\mathrm{C}-\mathrm{H}$ or C-C bond [21, 25, 26, 30]. Rhodium complexes (Table 1) were synthesized either by mixing and refluxing equimolar amount of the Schiff base with $\left\{\mathrm{RhCl}\left(\mathrm{Ph}_{3} \mathrm{P}\right)\right\}$ in THF for $0.5 \mathrm{~h}$ [31], or by boiling a solution of one equivalent of $\{\mathrm{Rh}(\mu-$ $\mathrm{Cl})(\mathrm{COD})\}_{2}$, with two equivalents of prepared Schiff base with four equivalents of phosphine in THF for $1 \mathrm{~h}$, as showed in Scheme (2). The ${ }^{1} \mathrm{H}$ NMR spectrum of each of the new rhodium complexes in $\mathrm{CDCl}_{3}$ shows a hydride resonance between $\delta-11.49$ and $\delta-13.27$ ppm (Table 3 ). The signals of the starting Schiff bases, C-H observed at $\delta 8.20-9.44 \mathrm{ppm}$ and in the resulting complex, these signals are absent, providing evidence for insertion of $\mathrm{Rh}$ complex into the $\mathrm{C}-\mathrm{H}$ bond of the imines. Strong confirmation evidence comes from appearance of the resonance of the hydride signal in each complex at high field $[24,29]$ ca. $\delta-12.38 \mathrm{ppm}$. The hydride signals in the complexes are split by coupling to an equivalent of two ${ }^{31} \mathrm{P}$ nuclei and the ${ }^{103} \mathrm{Rh}$ nucleus. The spin-spin couplings are frequently ca. $12.0 \mathrm{~Hz}$, the hydride multiplet observed as a pseudo quartet, but higher resolution frequency are usually appear as the expected doublet of triplets. The ${ }^{31} \mathrm{P}$, of rhodium complexes show a ${ }^{31} \mathrm{P}$ signal at ca. $\delta 28.2-$ 37.78 with $1 \mathrm{~J}\left({ }^{103} \mathrm{Rh}-{ }^{31} \mathrm{P}\right) 102.00-120.00 \mathrm{~Hz}$ as a doublet (Table 3) in keeping with previous report [30]. The majority of the rhodium imines hydride complexes are only moderately soluble in chloroform-d and dichlomethane-d2 solvents (complexes are soluble in DMSO, but decomposed during NMR processing).

The ${ }^{13} \mathrm{C}[1 \mathrm{H}]$ NMR spectrum, in particular the signal from the metal- carbon bonded atom, is consistent with the presence of the cyclometallated ring $[24,31,32]$ the signal 


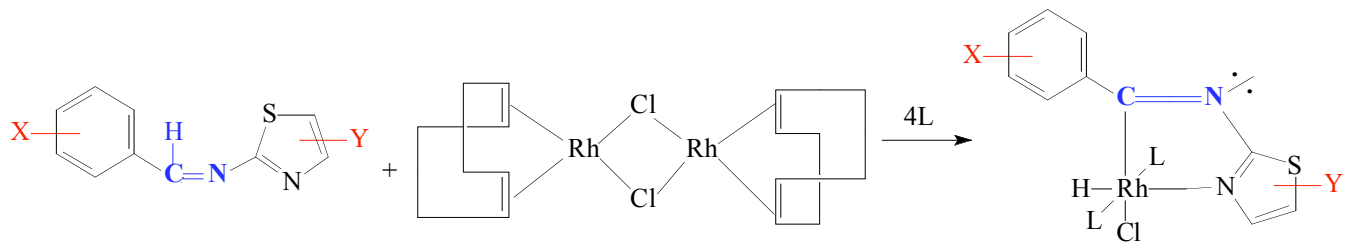

Scheme 1. Describes Schematic preparation and structural of iminothiazoles (1-20) chelating ligands.
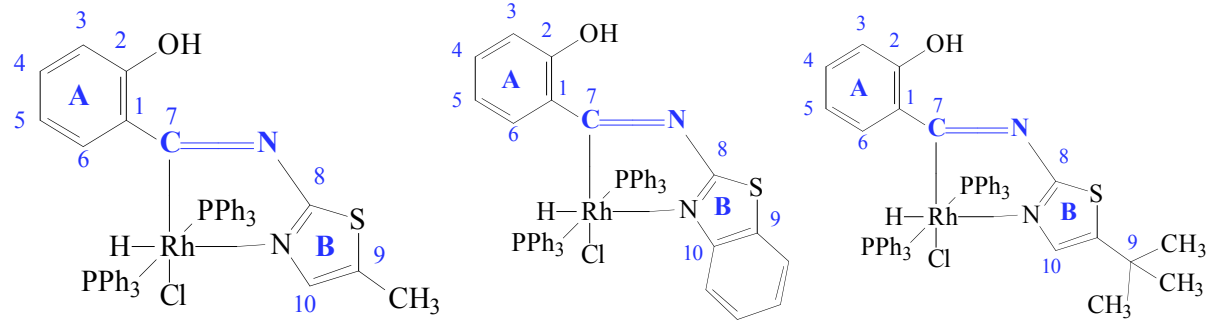

Scheme 2. Describes schematic diagram for preparation of "hydridothiazole" rhodium complexes.

Table 1. Describes the rhodium complexes obtained from Schiff bases derived from 2-amino thiazoles and benzaldehydes (complexes No. (21-29), 2-aminobenzothiazole and benzaldehyde (complex 30) and 2-amino-5-t-butyl-1, 3, 4-thiadiazoleand benzaldehydes (complex 31 ).

\begin{tabular}{|c|c|c|c|c|c|}
\hline 21 & $\mathrm{H}$ & $\mathrm{H}$ & 27 & $4-\mathrm{NO}_{2}$ & 4-Me \\
\hline 22 & $2-\mathrm{OH}$ & $\mathrm{H}$ & 28 & $\mathrm{H}$ & $5-\mathrm{Me}$ \\
\hline 23 & $4-\mathrm{NO}_{2}$ & $\mathrm{H}$ & 29 & $2-\mathrm{OH}$ & $5-\mathrm{Me}$ \\
\hline 25 & $2-\mathrm{OH}$ & 4-Me & 31 & $2-\mathrm{OH}$ & $2^{*}$ \\
\hline 26 & $\mathrm{H}$ & 4-Me & & & \\
\hline
\end{tabular}

Table 2. CHN-Elemental Analyses for Complexes No. (21-31).

\begin{tabular}{|c|c|c|c|c|c|c|c|c|c|}
\hline No. & $\mathbf{X}$ & M.P. $\left({ }^{\circ} \mathrm{C}\right)$ & M.F. & \multicolumn{3}{|c|}{ Calculated (\%) } & \multicolumn{3}{|c|}{ Found (\%) } \\
\hline 21. & $\mathrm{H}$ & 162 & $\mathrm{RhC}_{46} \mathrm{H}_{38} \mathrm{~N}_{2} \mathrm{SP}_{2} \mathrm{Cl}$ & 64.9 & 4.51 & 3.3 & 65.30 & 4.63 & 3.40 \\
\hline 22. & $2-\mathrm{OH}$ & 190 & $\mathrm{RhC}_{46} \mathrm{H}_{38} \mathrm{~N}_{2} \mathrm{SOP}_{2} \mathrm{Cl}$ & 63.70 & 4.53 & 3.23 & 64.70 & 5.01 & 3.34 \\
\hline 23. & $4-\mathrm{NO}_{2}$ & 185 & $\mathrm{RhC}_{46} \mathrm{H}_{37} \mathrm{~N}_{3} \mathrm{SO}_{2} \mathrm{P}_{2} \mathrm{Cl}$ & 61.7 & 4.16 & 4.7 & 60.66 & 4.26 & 4.34 \\
\hline 25. & $\mathrm{H}$ & 202 & $\mathrm{RhC}_{47} \mathrm{H}_{40} \mathrm{~N}_{2} \mathrm{SP}_{2} \mathrm{Cl}$ & 65.24 & 4.65 & 3.23 & 64.98 & 3.93 & 3.7 \\
\hline 26. & $2-\mathrm{OH}$ & 192 & $\mathrm{RhC}_{47} \mathrm{H}_{40} \mathrm{~N}_{2} \mathrm{SOP}_{2} \mathrm{Cl}$ & 64.06 & 4.89 & 3.17 & 63.13 & 4.44 & 2.95 \\
\hline 30. & $2-\mathrm{OH}$ & 70 & $\mathrm{RhC}_{50} \mathrm{H}_{40} \mathrm{~N}_{2} \mathrm{SOP}_{2} \mathrm{Cl}$ & 66.63 & 4.47 & 3.11 & 65.98 & 4.35 & 3.93 \\
\hline 31. & $2-\mathrm{OH}$ & 160 & $\mathrm{RhC}_{49} \mathrm{H}_{46} \mathrm{~N}_{3} \mathrm{SOP}_{2} \mathrm{Cl}$ & 64.47 & 5.09 & 4.62 & 65.01 & 4.89 & 4.35 \\
\hline
\end{tabular}


Table 3. $\quad{ }^{1} \mathrm{H}$, and ${ }^{31} \mathrm{P}-\mathrm{N} . \mathrm{M} . \mathrm{R}$. chemical shifts and ${ }^{2} \mathrm{~J}\left({ }^{31} \mathrm{P}-{ }^{1} \mathrm{H}\right),{ }^{1} \mathrm{~J}\left({ }^{103} \mathrm{Rh}-{ }^{1} \mathrm{H}\right)$ and ${ }^{1} \mathrm{~J}\left({ }^{103} \mathrm{Rh}-{ }^{31} \mathrm{P}\right)$ coupling constants of complexes No. (21-31). (In $\left.\mathrm{CDCl}_{3}\right)$.

\begin{tabular}{|c|c|c|c|c|c|c|c|}
\hline Comp. No. & $\mathbf{X}$ & $\mathbf{Y}$ & $\begin{array}{c}\delta^{1} H \text { Hydride } \\
\text { (p.p.m.) }\end{array}$ & $\begin{array}{r}\delta^{31} \mathbf{P}\left\{{ }^{1} \mathbf{H}\right\} \\
\text { (p.p.m.) }\end{array}$ & $\begin{array}{c}{ }^{2} \mathbf{J}\left({ }^{31} \mathbf{P}-{ }^{1} \mathbf{H}\right) \\
(\mathbf{H z})\end{array}$ & $\begin{array}{c}{ }^{1} \mathbf{J}\left({ }^{103} \mathbf{R h}-{ }^{1} \mathbf{H}\right) \\
(\mathrm{Hz})\end{array}$ & $\begin{array}{c}{ }^{1} \mathbf{J}\left({ }^{103} \mathrm{Rh}^{3}{ }^{31} \mathbf{P}\right) \\
(\mathbf{H z})\end{array}$ \\
\hline 21. & $\mathrm{H}$ & $\mathrm{H}$ & -12.09 & 28.7 & 12.0 & 12.4 & 102 \\
\hline 22. & $2-\mathrm{OH}$ & $\mathrm{H}$ & -12.30 & 31.4 & 12.0 & 12.4 & 107 \\
\hline 23. & $4-\mathrm{NO}_{2}$ & $\mathrm{H}$ & -12.05 & 29.0 & 12.0 & 12.7 & 107 \\
\hline 25. & $3-\mathrm{OH}$ & 4-Me & -12.36 & 32.35 & 12.0 & 12.50 & 111 \\
\hline 26. & $\mathrm{H}$ & 4-Me & -13.27 & 29.51 & 12.0 & 12.45 & 108 \\
\hline 27. & $4-\mathrm{NO}_{2}$ & 4-Me & -13.27 & 29.60 & 12.0 & 12.54 & 111 \\
\hline 30 & $2-\mathrm{OH}$ & - & -13.08 & 29.20 & 11.0 & 13.3 & 120 \\
\hline 31 & $2-\mathrm{OH}$ & - & $\begin{array}{l}-11.49 \\
-12.36\end{array}$ & $\begin{array}{l}37.87 \\
29.54\end{array}$ & $\begin{array}{l}11.0 \\
11.0\end{array}$ & $\begin{array}{l}12.50 \\
12.80\end{array}$ & $\begin{array}{l}111 \\
118\end{array}$ \\
\hline
\end{tabular}

Table 4. ${ }^{13} \mathrm{C}-\mathrm{NMR}$ chemical shifts for $\mathrm{C}(7)$ (iminoyl carbon- $\left.{ }^{13} \mathrm{C}=\mathrm{N}\right)$, and coupling constants ${ }^{1} \mathrm{~J}\left({ }^{103} \mathrm{Rh}-{ }^{31} \mathrm{P}\right) \mathrm{Hz}$ and ${ }^{2} \mathrm{~J}\left({ }^{103} \mathrm{Rh}-{ }^{31} \mathrm{P}\right) \mathrm{Hz}$.

\begin{tabular}{|c|c|c|c|c|}
\hline Complex No. & $\mathbf{X}$ & $\mathrm{C}(7)(\mathrm{ppm})$ & ${ }^{1} \mathrm{~J}\left({ }^{103} \mathrm{Rh}^{-31} \mathrm{P}\right)(\mathrm{Hz})$ & $\begin{array}{c}{ }^{2} \mathrm{~J}(\mathrm{~Hz}) \\
\left({ }^{103} \mathrm{Rh}-{ }^{31} \mathrm{P}\right)\end{array}$ \\
\hline 21. & $\mathrm{H}$ & 220.1 & 33 & 8 \\
\hline 22. & $2-\mathrm{OH}$ & 222.8 & 32 & 8 \\
\hline 23. & $4-\mathrm{NO}_{2}$ & 224.1 & 33 & 8 \\
\hline
\end{tabular}

from the metal-bonded carbon, C (7) (iminoyl carbon$13 \mathrm{C}=\mathrm{N}$ ) appears as a doublet of triplets owing to coupling to two equivalent $31 \mathrm{P}$ nuclei and the ${ }^{103} \mathrm{Rh}$ nucleus, whereas the corresponding signal from the uncomplexed Schiff base was found at $\delta 159.25-164.97 \mathrm{ppm}$ [24]. For C (7), $\delta$ - has been observed at low-field position in which a chelating atom is incorporated in a five member-ring [33], and this was expected for a cyclometallated $\mathrm{sp}^{2}$ carbon $[11,34]$ (similar to carbene-carbon. The remaining ${ }^{1} \mathrm{H}$ and ${ }^{13} \mathrm{C}$ NMR data are as expected. Table 4, demonstrate the ${ }^{13} \mathrm{C}-\mathrm{NMR}$ chemical shifts for $\mathrm{C}$ (7) (iminoyl carbon ${ }^{13} \mathrm{C}=\mathrm{N}$ ), and coupling constants $1 \mathrm{~J}$ $\left({ }^{103} \mathrm{Rh}^{-31} \mathrm{P}\right) \mathrm{Hz}$ and $2 \mathrm{~J}\left({ }^{103} \mathrm{Rh}-{ }^{31} \mathrm{P}\right) \mathrm{Hz}$. Complex No. X, C (7) (ppm) $1 \mathrm{~J}\left({ }^{103} \mathrm{Rh}-{ }^{31} \mathrm{P}\right)(\mathrm{Hz}) 2 \mathrm{~J}\left({ }^{103} \mathrm{Rh}-{ }^{31} \mathrm{P}\right)(\mathrm{Hz})$, respectively. No. $21, \mathrm{X}=\mathrm{H} ; 220.1 ; 33 ; 8$. No $22 ; \mathrm{X}=2-\mathrm{OH} ; 222.8 ; 32 ; 8$. No.23; $\mathrm{X}=4-\mathrm{NO}_{2} ; 224.1 ; 33.8$.No. $24 ; \mathrm{X}=4-\mathrm{Br} ; 222.0$; $32.0 ; 9$.The positions of the Rh-H signals in both IR (v RhH) $2073.48 \mathrm{~cm}-1$ for compound (24) and ${ }^{1} \mathrm{H}$ NMR $(\delta-11.49$ to $-13.27 \mathrm{ppm}$ ) spectra, are as expected for a $\mathrm{Rh}-\mathrm{H}$ bond located trans to the nitrogen-donor ligand. In addition, the $2 \mathrm{~J}$ $\left({ }^{31} \mathrm{P}-1 \mathrm{H}\right)$ value is consistent with a hydride located cis to two magnetically equivalent of $\mathrm{PPh}_{3}$ groups [35-37], which in turn are mutually trans, as confirmed from the ${ }^{31} \mathrm{P}\left({ }^{1} \mathrm{H}\right) \mathrm{NMR}$ spectrum. Interestingly, the hydride ${ }^{1} \mathrm{H}$ NMR spectrum of compound (31) presented in two types of the hydride spectrum which appear at $\delta-11.49 \mathrm{ppm}$ and $-12.36 \mathrm{ppm}$. Also, two ${ }^{31} \mathrm{P}$-spectrum appears at $\delta 37.87 \mathrm{ppm}$ and $\delta 29.54 \mathrm{ppm}$ with $2 \mathrm{~J}\left({ }^{31} \mathrm{P}-{ }^{1} \mathrm{H}\right), 11.0$ and $11.0 \mathrm{~Hz}$ and $1 \mathrm{~J}\left({ }^{103} \mathrm{Rh}-{ }^{1} \mathrm{H}\right) 12.50$ $\mathrm{Hz}$ and $12.80 \mathrm{~Hz}$ with $1 \mathrm{~J}\left({ }^{103} \mathrm{Rh}^{31}{ }^{31} \mathrm{P}\right)$, of $111 \mathrm{~Hz}$ and $118 \mathrm{~Hz}$ respectively. This result may be due to the presence of tbutyl group at C-5 of the thiazole ring, which leads to different geometric structure. It was also observed that the signal for $\mathrm{C}$ (7) (iminoyl carbon- ${ }^{13} \mathrm{C}=\mathrm{N}$ ) is at low magnetic field, at $\delta 224.1 \mathrm{ppm}$, this may be due to the substitution of $4-\mathrm{NO}_{2}$ (at para-position in aryl ring), as electron withdrawing group, which leads to decrease in the electronic density on C-7 led $\delta$-moved to low magnetic field, compared with other groups on aryl ring of the same complexes.

\section{CONCLUSION}

The new cyclometallated complexes have been characterized by elemental analysis, IR, ${ }^{1} \mathrm{H},{ }^{13} \mathrm{C}-\mathrm{NMR}$ and ${ }^{31} \mathrm{P}$ (only the more soluble complexes were recorded in $\left.\mathrm{CDCl}_{3}\right)$ spec- 
troscopy. Interestingly, the hydride ligand signals in both IR $\left(2040 \mathrm{~cm}^{-1}\right)$ and ${ }^{1} \mathrm{H}-\mathrm{NMR}, \delta((-14.60)-(-15.04)) \mathrm{ppm}$. The result obtained from the spectra was expected for Rh hydride atom trans position to the N-donor ligand. However, the ${ }^{31} \mathrm{P}$-NMR for some cyclometallated complexes shows signal at $\delta(30.20-34.67) \mathrm{ppm}$. The $2 \mathrm{~J}\left({ }^{31} \mathrm{P}-{ }^{1} \mathrm{H}\right)$ value consistent for $\mathrm{H}$ cis is to two magnetically equivalent $\mathrm{PPh}_{3}$-groups, which indicate mutually trans, as observed from the ${ }^{31} \mathrm{P}\left({ }^{1} \mathrm{H}\right)$ NMR spectrum. This result supported from ${ }^{1} \mathrm{H}$ and ${ }^{13} \mathrm{C}-\mathrm{NMR}$ spectra. Interestingly, the ${ }^{13} \mathrm{C}-\mathrm{NMR}$ of the iminoyl carbon $(7 \mathrm{C}=\mathrm{N})$ signal in $\mathrm{Rh}(\mathrm{III})$ observed at $\delta(220.1-237.6) \mathrm{ppm}$. This low-field position for cyclometallated complexes is suggestive of carbene -like properties.

\section{CONFLICT OF INTEREST}

The authors confirm that this article content has no conflict of interest.

\section{ACKNOWLEDGEMENTS}

The authors would like to thank the Research Center, College of Science, Princess Nora University and King Abdulaziz City for Science and Technology for the financial support to this Research Project (AT-17-171).

\section{REFERENCES}

[1] Jonson, K.R.D.; Hayes, P.G. Cyclometalative C-H bond activation in rare earth and actinide metal complexes. Chem. Soc. Rev., 2013, 42, 1947-1960.

[2] Deng, Y.; Gong, W.; He, J.; Yu, J-Q. Ligand-enable Triple C-H activation reactions: one-pot synthesis of diverse 4-aryl-2quinolinones from propionamides. Angew. Chem. Int. Ed., 2014, 53, 6692-6695.

[3] de Almeida, K. J.; Ramalho, T.C.; Neto, J.L.; Santiago, R.T.; Felicíssimo, V.C.; Duarte, H.A. Methane dehydrogenation by niobium ions: a first-principles study of the gas-phase catalytic reactions. Organometallics, 2013, 32(4), 989-999.

[4] Lu, F.; Li, J.; Sun, H.; Li. X. Selective C-H bond activation of 1,2,4,5-tetrafluorobenzene by $\mathrm{Co}\left(\mathrm{PMe}_{3}\right)_{4}$. Inorganica Chimica Acta, 2014, 416, 222-225.

[5] Benett, R.L.; Bruce, M.I.; Matsuda, I.; Doednes, R.J.; Little, R.G.; Veal, J.T. Ortho-metallation of a sulphur-donor ligand: preparation structure of $\mathrm{C}_{6} \mathrm{H}_{4} \mathrm{CH}_{2} \mathrm{SMeMn}(\mathrm{CO})_{3}\left(\mathrm{PPH}_{3}\right)$. J. Org. Chem,, 1974, 67(3), 19. C72-C74

[6] Benett, R.L.; Bruce, M.I.; Stone, F.G.A. Cyclometallation reactions XII: on the effect of various leaving groups on internal metallation reactions with alkyl manganese complexes. J. Organomet. Chem., 1975, 94(1), 65-74.

[7] Hill, A.F. Organotransition Metal Chemistry, Publisher: R.S.C, publication Date: 2003, 22, 3566-3576.

[8] Werner, H.; Mahr, N.; Wolf, J.; Fries, A.; Laubenden, M.; Bleuel, E.; Garde, R.; Laubenden, P.; Bleuel, E.; Garde R.; Lahuerta, P. Synthesis, molecular structure, and reactivity of rhodium (1) complexes with diazoalkanes and related substrates as ligands. Organometalics, 2003, 22, 3566-3576.

[9] Krug, C.; Hartwig, J.F. Imine Insertion into a late metal-carbon bond to form a stable amido complex. J. Am. Chem. Soc., 2004, 126, 2694-2695.

[10] Marcazzan, P.; Patrick, B.O.; James, B.R. Rhodium (III)cyclometalated-imine complexes: solution behavior and reactivity with molecular hydrogen. Organometallics, 2005, 24, 1445-1451.

[11] El-Baih, F.E.M.; Abu-Loha, F.M.; Gomaa, Z.; Al-Najjar, I.M. Synthesis and characterization of some rhodium (III) cyclometallated complexes of 2-substituted benzylideneamino thiazoles. Transition Met. Chem., 1994, 19, 325-328.
[12] Leung, C.H.; He, H.Z.; Liu, L.J.; Wang, M.; Chan, D.S.H.; Ma, D.L. Metal complexes as inhibitors of transcription factor activity. Coord. Chem. Rev., 2013, 257, 3139-3151.

[13] Zhong, H.J.; Leung, K.H.; Liu, L.J.; Lu, L.; Chan, D.S.; Leung, C.H.; Ma, D.L. Antagonism of mTOR activity by a kinetically inert rhodium(III) complex. Chem. Plus Chem., 2014, 79, 508-511.

[14] Liu, L.-J.; Lin, S.; Hin-Chan, S.L.; Vong; C.T., Hoi, P.M.; Wong, C-U; Ma, D.-L. J. A rhodium(III) complex inhibits LPS-induced nitric oxide production and angiogenic activity in cellulo. Inorg. Biochem, 2014, 140, 23-28.

[15] Ma, D.L.; Liu, L.J.; Leung, K.H.; Chen, Y.T.; Zhong, H.J.; Chan, D.S.H.; Wang, H.M.D.; Leung, C.H. Antagonizing STAT3 dimerization with a rhodium (III) complex. Angew. Chem. Int. Ed. Engl., 2014, 53(35), 9178-82.

[16] Leung, C.H.; Yang, H.; Ma, V.P.Y., Chan, D.S.H.; Zhong, H.J.; Li, Y.W.; Fong, W.F.; Ma, D.L. Inhibition of janus kinase 2 by cyclometalated rhodium complexes. Med. Chem. Comm., 2012, 3, 696698.

[17] Giopdano, G.; Crabtree, R.H. Di-p-chloro-bis (g4-115cyclooctadiene)-dirhodium (1). Inorg. Synth., 1974, 19, 318-220.

[18] Colquhonn, H.M.; Holton, J.; Thompson; Wigg, M.V. New pathways for Organic synthesis. Plenum Press: New York and London, 1984; pp 380-390.

[19] Dehand, J.; Pfeffer, M. Cyclometallated compounds. Coord. Chem. Rev., 1976, 18(3), 327-352.

[20] Albinati, A.; Anklin, C.G.; Ganazzoli, F.; Ruegg. H.; Pregosin, P.S. Preparative and ${ }^{1} \mathrm{H}$ NMR spectroscopic studies on palladium (II) and platinum (II) quinoline-8-carbaldehyde (1) complexes. x-ray structures of the cyclometalated acyl complex $\left.\mathrm{PdCI}\left(\mathrm{C}(\mathrm{O}) \mathrm{C}_{9} \mathrm{H}_{6} \mathrm{~N}\right) \mathrm{Ph}_{3}\right) \mathrm{PPh}_{3}$ and trans $-\mathrm{P} 1 \mathrm{Cl}_{2}$ (I) $\left(\mathrm{Pet}_{3}\right)$. Inorg. Chem., 1987, 26, 503-508.

[21] Suggs, J.W.; Wovkulich, M.J.; Cox, S.D. Synthesis, structure and ligand-promoted reductive elimination in an acylrhodium ethyl complex. Orgtanometallics, 1985, 4(6), 1101-1107.

[22] Garber, A.R.; Garron, P.E.; Hartwell, G.E.; Smas, M.J.; Wilkinson, J.R.; Todd, I.J. Application of carbon-13 NMR to the determination of metal-carbon: sigma bond formation in cyclometalation reactions with nitrogen donor ligands. J. of Organomet. Chem., 1975, 86(2), 219-227.

[23] Suggs, J.W.; Chul-Ho, J. Metal-catalysed alkyl ketone conversions in chelating ketones via carbon-carbon bond cleavage. J. Chem. Soc., Chem. Commun., 1985, 92-93.

[24] Dowerah, D.; Radonovich, L.J.; Woolsey, J.F.; Heeg, M.J. Reaction of 2-(alpha-R-Benzylidene) amino) pyridines $\mathrm{LBR}$ equals $\mathrm{CH}_{3}$, 4- $\left(\mathrm{CH}_{3} \mathrm{O}\right), \mathrm{C}_{6} \mathrm{H}_{4}$ with $\mathrm{RhCl}(\mathrm{L})_{3}$ or $\mathrm{Rh}_{2} \mathrm{Cl}_{2}(\mathrm{CO})_{4}$ : formation and structure of a rhodium (II) dimer. Organometallics, 1990, 9(3), pp. 614-620.

[25] Sprouse, S.; King, K.A.; Spellane, P.J.; Watts, P.; Richard, J. Photophysical effects of metal-carbon sigma bonds in orthometalated complexes of Iridium (III) and rhodium (III). J. Am. Chem. Soc., 1984, 106(22), 6647-6653.

[26] Perera, S.D.; Shaw, B.L.; Thornton-Pett, M. General strategy for inducing $\mathrm{C}-\mathrm{H}$ bond fission (Cycloirradiation) in some aryl, heterocyclic, alkenyl or alkyl groups in azines derived from aldehydes or methyl ketones. J. Chem. Soc., Dalton Trans., 1995, 10, 16891696.

[27] Suggs, J.W. Activation of aldehyde carbon-hydrogen bonds to oxidative addition via formation of 2-methyl-2-aminopyridyl aldimines and related compounds: rhodium based catalytic hydroacylation. J. Amer. Chem. Soc., 1979, 101(2), 489.

[28] Suggs, J.W.; Chul-Ho. Synthesis of a chiral rhodium alkyl via metal insertion into an unstrained $\mathrm{C}-\mathrm{C}$ bond and use of the rate of racemization at carbon to obtain a rhodium-carbon bond dissociation Energy. J. Amer. Chem. Soc., 1986, 108, 4679-4681.

[29] Suggs, J.W.; Chul-Ho. J. Directed cleavage of carbon-carbon bonds by transition metals: the alpha-bonds of ketones. J. Amer. Chem. Soc., 1984, 106(10), 3054-3056.

[30] Albinati, A.; Arz, C.; Pregosin, P.S. Synthesis, structure and NMR spectroscopy of some rhodium (III) cyclometalated Schiff's base complexes derived from 2-benzylidene-3-methypyridines: crystal structure of (RHHI (2(3-nitrobenzylidene)-3-methyl-pyridine) 
(RhHI(2-(3nitrobenzyli-dene)-3-methyl-pyridine)( $\left.\left(\mathrm{PPh}_{3}\right)_{2}\right) . \quad J . \quad$ Organomet. Chem., 1987, 35(3), 379-394.

[31] Janecki, T.; Jeffreys, J.A.D.; Pauson, P.L.; Pietrzykrowski, A.; McCullough, K.J. Bis-orthometalated palladium complexes, new examples and reactivity: the $\mathrm{x}$-ray crystal structure of cis-(2$\left.\mathrm{C}_{6} \mathrm{H}_{5} \mathrm{~N}-\mathrm{NC}_{6} \mathrm{H}_{4}\right)_{2} \mathrm{Pd}$ and cis- $\left.\left(2-\mathrm{C}_{6} \mathrm{H}_{5} \mathrm{~N}-\mathrm{NC}_{6} \mathrm{H}_{4}\right)\right)\left(2-\mathrm{Me}_{2} \mathrm{nCH}_{2} \mathrm{C}_{6} \mathrm{H}_{4}\right)$ Pd. Organometallics, 1987, 6, 1553-1560.

[32] Giordano, G.; Crabtree, R.H. Di-mu-chloro-bis (eta. 4-1, 5cyclooctadiene) dirhodium(I). Inorg. Synth. 1979, 19, 218-220.

[33] Colquhonn, H.M.; Holton, J.; Thomspon, D.J.; Wigg, M.V. New pathways for organic synthesis: practical application of transition metals. Plenum Press: New York, 1984.
[34] Pregosin, P.S.; Kunz, R.W. N.M.R. Basic Principle and progress, Berlin: Springer Verlag, 1979.

[35] Pregosin, P.S.; Kunz, R.W. Phosphorus-31 and Carbon-13 NMR of transition metal phosphine complexes. N.M.R. Basic principle and progress, Berlin: Springer Verlag, 1979.

[36] Al-Najjar, I.M.; Al-Showiman, S.S.; Al-Hazmi, H.M. Multinuclear NMR studies on new platinum imine complexes. Inorg. Chim. Acta, 1984, 89(1), 57-63.

[37] Garrow, P.E. $\Delta$ R ring contribution to ${ }^{31} \mathrm{P}$ NMR parameters of transition-metal-phosphorus chelate complexes. Chem. Rev., 1981, 81, 229-266.

Received: May 27, 2014

Revised: October 30, 2014

Accepted: November 18, 2014

(C) Al-hamidi et al.; Licensee Bentham Open.

This is an open access article licensed under the terms of the Creative Commons Attribution Non-Commercial License (http://creativecommons.org/licenses/by-nc/3.0/) which permits unrestricted, non-commercial use, distribution and reproduction in any medium, provided the work is properly cited. 